\title{
Making of Kashkaval cheese from bovine micellar casein powder
}

\author{
Jeliazko SIMOVa*, Jean-Louis MAUBOIS ${ }^{\mathrm{b}}$, Anita GAREM ${ }^{\mathrm{b}}$, Bénédicte CAMIER ${ }^{\mathrm{b}}$ \\ a Département de Technologie du Lait et des Produits Laitiers, Université des Technologies Alimentaires, \\ Plovdiv, Bulgaria \\ b UMR 1253, Science et Technologie du Lait et de l'Euf, Inra-Agrocampus Rennes, \\ 65 rue de Saint-Brieuc, 35042 Rennes Cedex, France
}

Received 7 January 2004 - Accepted 13 April 2005

Published online 1 October 2005

\begin{abstract}
Enrichment in micellar casein of bovine milk for making Kashkaval cheese was studied in order to face yearly variations in the composition of collected milk. Increase in casein content from $22.90 \pm 0.01 \mathrm{~g} \cdot \mathrm{kg}^{-1}$ to $26.10 \pm 0.02 \mathrm{~g} \cdot \mathrm{kg}^{-1}$ did not request change in the process parameters and led to cheeses with typical texture and an increase in the recovery of fat and casein in the cheese due to the acceleration of the organisation of the rennet curd matrix and a greater final firmness. The cheese yield was increased by $16.9 \%$. On the other hand, increase in casein content to $29.20 \pm$ $0.02 \mathrm{~g} \cdot \mathrm{kg}^{-1}$ led to a high increase in the vat acidification and to an unsatisfactory cheddaring step, which consequently involved protein losses in the draining whey.
\end{abstract}

micellar casein / standardisation / Kashkaval / rennet coagulation / cheddaring / cheese yield

摘要 - 应用牛乳酪蛋白粉的生产 Kashkaval 干酪。本文主要研究了应用富含酪蛋白的牛乳 生产 Kashkaval 干酪, 目的是解决每年收购的原料奶质量不稳定的问题。酪蛋白含量由 $22.90 \pm 0.01 \mathrm{~g} \cdot \mathrm{kg}^{-1}$ 增加到 $26.10 \pm 0.02 \mathrm{~g} \cdot \mathrm{kg}^{-1}$ 时, 不需要改变工艺参数, 由于酪蛋白含量增加 加速了凝乳基质的形成, 最终形成的凝块硬度较高, 使得加工出的干酪具有典型的质构, 而且增加了酪蛋白和脂肪的回收率。干酪的产量增加到 $16.9 \%$ 。另一方面, 当酪蛋白含量 增加到 $29.20 \pm 0.02 \mathrm{~g} \cdot \mathrm{kg}^{-1}$ 时, 会加速罐中的酸化反应, 并且在排乳清的过程中蛋白质流失, 导致堆酿效果不理想。

\section{酪蛋白胶团 / 标准化 / Kashkaval / 酶凝固 / 堆酿 / 干酪产量}

Résumé - Fabrication de Kashkaval à partir de lait enrichi en caséine micellaire. La transformation de laits de vache enrichis en caséine micellaire en fromage Kashkaval a été étudiée dans le but d'utiliser cette standardisation pour pallier les variations annuelles de composition des laits collectés. L'accroissement de la teneur en caséine de $22,90 \pm 0,01 \mathrm{~g} \cdot \mathrm{kg}^{-1}$ à $26,10 \pm 0,02 \mathrm{~g} \cdot \mathrm{kg}^{-1}$ ne requiert aucune modification du procédé de fabrication et conduit à des fromages de texture typique et à une rétention accrue de la matière grasse et de la caséine dans le fromage en raison d'une cinétique d'organisation accélérée et d'une fermeté finale supérieure du coagulum présure. L'augmentation du rendement en fromage déterminée était de 16,9\%. Par contre, l'accroissement de la teneur en caséine à 29,20 $\pm 0,02 \mathrm{~g} \cdot \mathrm{kg}^{-1}$, en raison de l'élévation du pouvoir tampon du caillé, entraînait un allongement de son acidification et ne permettait pas une « cheddardisation » satisfaisante, ce qui conduisait à des pertes en protéines dans le lactosérum d'égouttage.

phosphocaséinate natif / standardisation / coagulation présure / cheddardisation / Kashkaval / rendement fromager

*Corresponding author (通讯作者): simov_z@yahoo.com 


\section{INTRODUCTION}

Use of cheese milk with a standardised increased content in native micellar casein by membrane microfiltration (MF) as proposed by Maubois et al. [11] is increasing for the making of both traditional and new varieties of cheese. In addition to the potential high added value of the obtained coproduct "the ideal whey", the use of the casein-enriched milk leads to an improvement of the technological properties: acceleration of the development of curd firmness, increased firmness and consequently, a higher cheese yield resulting from the decrease in losses in curd fines in the expelled traditional whey $[4,11,14-16]$.

Enrichment of cheese milk in native micellar casein can be realised daily in plants possessing the required specific MF equipment but it can also be done by adding sporadically native micellar casein powder prepared as described by Pierre et al. [12], Schuck et al. [16] and Saboya and Maubois [13] at periods of the year where the casein content of the collected milk is low.

The aim of this study was to determine the effects of standardisation of the casein content of bovine milk by addition of native micellar casein on the technological parameters, qualities and cheese yield during the process of making "Kashkaval" cheese, one of the most popular Balkan cheese varieties [8].

\section{MATERIALS AND METHODS}

\subsection{Milk and cheese-making process}

The skim milk (heat-treated at $63{ }^{\circ} \mathrm{C}-30 \mathrm{~s}$ ) and cream used were from an industrial plant (C.L.E., Montauban de Bretagne, France). Calcium chloride solution was from Humeau Laboratory (Nantes, France). Rennet extract (chymosin $520 \mathrm{mg} \cdot \mathrm{L}^{-1}$ ) was from Gand-Gassiot (Lyon, France).

The native micellar casein (NMC) solution used for enrichment of the cheese milk was prepared as follows : NMC powder with a casein content of $748.5 \mathrm{~g} \cdot \mathrm{kg}^{-1}$ (analytical characterisation is given in Tab. I) was added to distilled water at $50{ }^{\circ} \mathrm{C}$ and thoroughly homogenised with an Omni-Mixer
Table I. Analytical characterisation of native micellar casein powder.

\begin{tabular}{lc}
\hline Contents $\left(\mathrm{g} \cdot \mathrm{kg}^{-1}\right)$ & \\
\hline Total solids & 919.80 \\
$\mathrm{TNM}(\mathrm{N} \times 6.38)$ & 822.90 \\
$\mathrm{NCN}$ & 74.30 \\
$\mathrm{NPN}$ & 5.90 \\
Casein & 748.60 \\
Lactose & 18.20 \\
Ashes & 79.50 \\
Ca total & 28.50 \\
Na total & 0.10 \\
P total & 16.40 \\
\hline Properties & \\
\hline pH $\left(10 \%\right.$ TS at $\left.20^{\circ} \mathrm{C}\right)$ & 7.09 \\
Solubility $\left(\mathrm{ADPI}-24{ }^{\circ} \mathrm{C}\right)$ & $>72.0 \%$ \\
Dispersibility $\left(20^{\circ} \mathrm{C}\right)$ & $>20 \%$ \\
Mouillability $\left(20^{\circ} \mathrm{C}\right)$ & $>60 \mathrm{~s}$ \\
Water activity $\left(25^{\circ} \mathrm{C}\right)$ & 0.28 \\
\hline
\end{tabular}

Homogeniser running at $10000 \mathrm{rpm}$ for $10 \mathrm{~min}$; the solution obtained (casein content: $125 \mathrm{~g} \cdot \mathrm{kg}^{-1}$ ) was cooled down at $4{ }^{\circ} \mathrm{C}$ for 12 to $14 \mathrm{~h}$ and then heated to $20{ }^{\circ} \mathrm{C}$ before addition to reference skim milk.

Starters were prepared as follows: addition of frozen active specific strains of Lactobacillus bulgaricus and Streptococcus thermophilus in a ratio $1: 1$ to $2 \mathrm{~L}$ of sterile $\left(110{ }^{\circ} \mathrm{C}-20 \mathrm{~min}\right)$ skim milk, incubated at $43{ }^{\circ} \mathrm{C}$ until it reached a $\mathrm{pH}$ of 4.25 and a titrable acidity of $90^{\circ} \mathrm{D}$; then, distributed in sterile bottles. Lactococcus helveticus starter was prepared from the same sterile skim milk, but with incubation at $37^{\circ} \mathrm{C}$ for $18 \mathrm{~h}$ until it reached $\mathrm{pH} 4.20$ and a titrable acidity of $90^{\circ} \mathrm{D}$. Sterile bottles of each starter were frozen at $-25^{\circ} \mathrm{C}$, and before use, frozen starters were thawed in a cold room $\left(+4{ }^{\circ} \mathrm{C}\right)$ for 12 to $14 \mathrm{~h}$ and then thoroughly mixed in a ratio $1: 1$.

Reference skim milk with a low casein content $\left(22.90 \pm 0.01 \mathrm{~g} \cdot \mathrm{kg}^{-1}\right)$ was prepared by diluting industrial skim milk at $20^{\circ} \mathrm{C}$ with sterile water (casein content: $27 \mathrm{~g} \cdot \mathrm{kg}^{-1}$ ). Then, pasteurised cream (fat content: $380 \mathrm{~g} \cdot \mathrm{kg}^{-1}$ ) was added in order to obtain a 
cheese milk with a fat content of $29.20 \pm$ $0.02 \mathrm{~g} \cdot \mathrm{kg}^{-1}$ and a casein/fat ratio of $0.78 \pm 0.03$.

Experimental casein-enriched milks: in reference low-casein skim milk, NMC solution was added in order to obtain casein contents of $26.10 \pm 0.02 \mathrm{~g} \cdot \mathrm{kg}^{-1}$ and $29.20 \pm$ $0.02 \mathrm{~g} \cdot \mathrm{kg}^{-1}$. Then, cream was added to obtain a casein/fat ratio of $0.78 \pm 0.03$ and thoroughly mixed. "Kashkaval" cheeses were made according to the traditional process $[3,8]$ through the use of $10-\mathrm{L}$ microvats type CF $10 \mathrm{~L}$, Microcor III PR (Pierre Guérin, Niort, France).

\subsection{Analytical determinations}

Milk, cream, whey, NMC solution and cheese samples were characterised through the following : $\mathrm{pH}$ at $20^{\circ} \mathrm{C}$, titrable acidity in ${ }^{\circ} \mathrm{D}$, total solids $\left(7 \mathrm{~h}\right.$ in an oven at $102^{\circ} \mathrm{C}$ $-105^{\circ} \mathrm{C}$ ), fat by acid butyrometric Gerber's method, chloride by chloride meter (equipment 926, Corning, Medfield, USA), Total Nitrogen Matter $(\mathrm{TNM})(\mathrm{N} \times 6.38)$ by Kjeldhal (Kjeltec Auto 1035, Foss Electric, Hoganas, Sweden), non-casein nitrogen (NCN), non-protein nitrogen (NPN) according to Aschaffenburg et Drewy [1], ashes at $550^{\circ} \mathrm{C}$ by the AOAC method, total contents in $\mathrm{Ca}, \mathrm{K}, \mathrm{Na}$ and $\mathrm{Mg}$ by atomic absorption spectrophotometry on Varian 330 equipment (Les Ulis, France) according to Brulé et al. [2], and phosphorus content according to the IDF standard [6].

Water activity $\left(a_{w}\right)$ in the cheeses was determined with a Novasina aw-Centers (Pfäffikon, Switzerland) at $25^{\circ} \mathrm{C}$.

The rennet coagulation properties of the milks were determined with Formagraph equipment (Foss Electric, Nanterre, France) by the measurement of 4 parameters: coagulation time $\mathrm{R}$ in minutes, firmness kinetics by $\mathrm{K} 20$ in minutes and aR and a2R in $\mathrm{mm}$, respectively, coagulum firmness after times equal to once and twice R. For these determinations, milk samples were maintained at $33{ }^{\circ} \mathrm{C}$ for one hour in order to reestablish casein and mineral equilibria, and $\mathrm{pH}$ was adjusted to 6.50. Then, $10 \mathrm{~mL}$ of each milk sample were renneted with $50 \mu \mathrm{L}$ of a rennet commercial extract, diluted 20 times.
All results are the average of 4 experiments or determinations.

The buffering capacity of all milks was determined through the use of lactic acid $0.13 \mathrm{~mol} \cdot \mathrm{L}^{-1}$ up to $\mathrm{pH} 4.60$, according to Brulé et al. [2].

Triplicate experiments on the pilot scale with $20 \mathrm{~kg}$ of each cheese milk allowed the determination of the proportions of total solids, fat and TNM recovered in the cheeses. The proportions of fat and TNM recovered in the cheese as well as the real cheese yield at $d+1$ and the corrected cheese yield (adjustment of the weight of cheese at $40 \%$ moisture expressed in $\mathrm{kg}$ of cheese obtained for $100 \mathrm{~kg}$ of cheese milk) were calculated according to the equations described by Vandeweghe [17].

\section{RESULTS AND DISCUSSION}

The composition, $\mathrm{pH}$ and titrable acidity of the cheese milks carried out in the study are summarised in Table II. As expected, addition of NMC increased not only casein and TNM contents but also total ashes and $\mathrm{Ca}$ contents because of the Ca Phosphate salts bound to micellar casein. This increase in casein content $\left(+3.2\right.$ and $+6.3 \mathrm{~g} \cdot \mathrm{kg}^{-1}$ for $\mathrm{E}_{1}$ milks and $\mathrm{E}_{2}$ milks) and in ashes (+ 0.2 and $+0.5 \mathrm{~g} \cdot \mathrm{kg}^{-1}$ for $\mathrm{E}_{1}$ milks and $\mathrm{E}_{2}$ milks) originated an increase in the buffering capacity of the casein-enriched cheese milks (Fig. 1). To reach $\mathrm{pH} 4.60$, addition of $26 \mathrm{~mL}$ of a $0.13 \mathrm{~mol} \cdot \mathrm{L}^{-1}$ lactic acid solution was requested for reference milk vs., respectively, 32 and $36 \mathrm{~mL}$ for trials $\mathrm{E}_{1}$ and $\mathrm{E}_{2}$. If rennet coagulation time was not affected by casein increase in cheese milks as shown by Maubois and Mocquot [10] and Garnot [7], other parameters (K20, aR and a2R) describing the organisation of coagulum kinetic and final curd firmness were affected as indicated in Figure 2 and thus, in agreement with the results obtained by Daviau et al. [5].

One of the key steps of the making process of Kashkaval is the cheddaring one, which is ruled by numerous parameters, reviewed by Lawrence et al. [9]. Among them, the most important is the extent of 


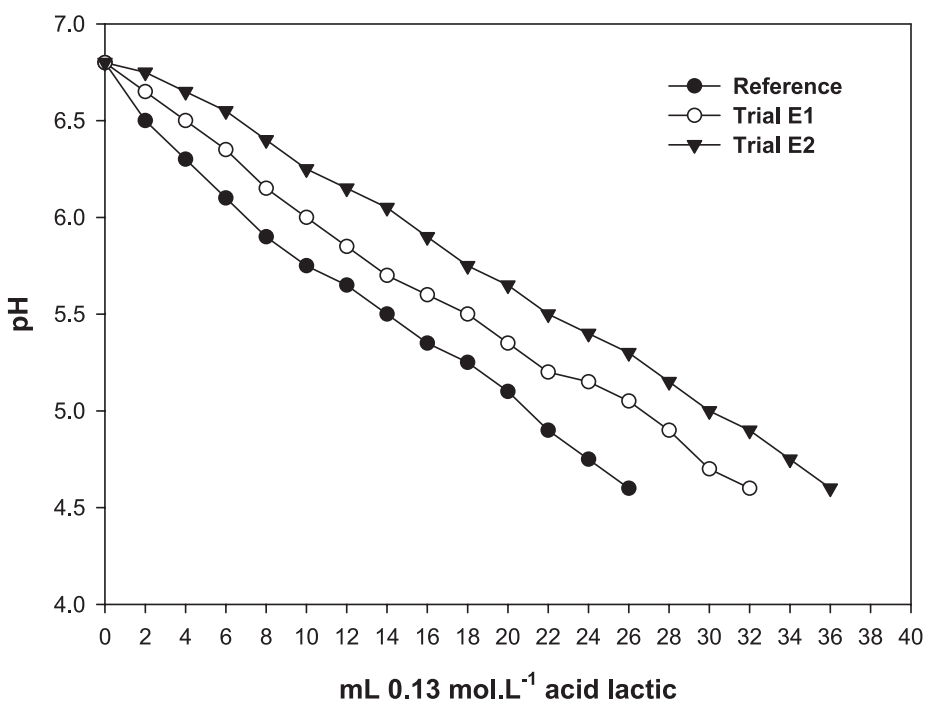

Figure 1. Variation in buffering capacity according to the casein content.

Table II. Analytical characterisation of the cheese milks.

\begin{tabular}{lccc}
\hline Contents & \multicolumn{3}{c}{ Cheese milks } \\
\cline { 2 - 4 } & Reference & Trial $\mathrm{E}_{1}$ & Trial $\mathrm{E}_{2}$ \\
\hline Total solids $\left(\mathrm{g} \cdot \mathrm{kg}^{-1}\right)$ & $109.80 \pm 0.32$ & $116.60 \pm 0.28$ & $123.40 \pm 0.32$ \\
Fat $\left(\mathrm{g} \cdot \mathrm{kg}^{-1}\right)$ & $29.50 \pm 0.20$ & $33.50 \pm 0.22$ & $37.20 \pm 0.23$ \\
$\mathrm{TNM}(\mathrm{N} \times 6.38)\left(\mathrm{g} \cdot \mathrm{kg}^{-1}\right)$ & $29.80 \pm 0.07$ & $33.30 \pm 0.06$ & $36.50 \pm 0.07$ \\
$\mathrm{NCN}\left(\mathrm{g} \cdot \mathrm{kg}^{-1}\right)$ & $6.90 \pm 0.04$ & $7.20 \pm 0.05$ & $7.30 \pm 0.04$ \\
$\mathrm{NPN}\left(\mathrm{g} \cdot \mathrm{kg}^{-1}\right)$ & $1.60 \pm 0.02$ & $1.70 \pm 0.02$ & $1.72 \pm 0.02$ \\
Casein $\left(\mathrm{g} \cdot \mathrm{kg}^{-1}\right)$ & $22.90 \pm 0.01$ & $26.10 \pm 0.02$ & $29.20 \pm 0.02$ \\
Ashes $\left(\mathrm{g} \cdot \mathrm{kg}^{-1}\right)$ & $6.70 \pm 0.05$ & $6.90 \pm 0.05$ & $7.20 \pm 0.06$ \\
Ca total $\left(\mathrm{mg} \cdot \mathrm{kg}^{-1}\right)$ & $1100 \pm 10.8$ & $1210 \pm 12.9$ & $1320 \pm 13.2$ \\
Casein/Fat & $0.78 \pm 0.03$ & $0.78 \pm 0.03$ & $0.78 \pm 0.03$ \\
Casein/TNM $(\%)$ & $77 \pm 0.50$ & $80 \pm 0.45$ & $81 \pm 0.53$ \\
$\mathrm{pH}\left(\mathrm{at} 20^{\circ} \mathrm{C}\right)$ & $6.78 \pm 0.04$ & $6.79 \pm 0.04$ & $6.79 \pm 0.04$ \\
Acidity $\left({ }^{\circ} \mathrm{D}\right)$ & $16.0 \pm 0.05$ & $16.0 \pm 0.05$ & $16.0 \pm 0.05$ \\
\hline
\end{tabular}

acid production in the vat, which largely determines the solubilisation of colloidal calcium, the concomitant disaggregation of casein micelles and the rate and the composition of the expelled whey. The resulting curd, mainly formed of monocalcium paracaseinate, has the right composition for the specific texturising following steps (mechan- ical kneading and stretching in hot brine) [8]. Probably because of their higher buffering capacity, acidification in the $\mathrm{E}_{2}$ bench trials to reach $\mathrm{pH} 5.1$ took more time than for the reference and $\mathrm{E}_{1}$ trials (250 min instead of $150 \mathrm{~min}$ ) as shown in Figure 3. Such an increase in the processing time added to the very bad texturising ability seen and the 

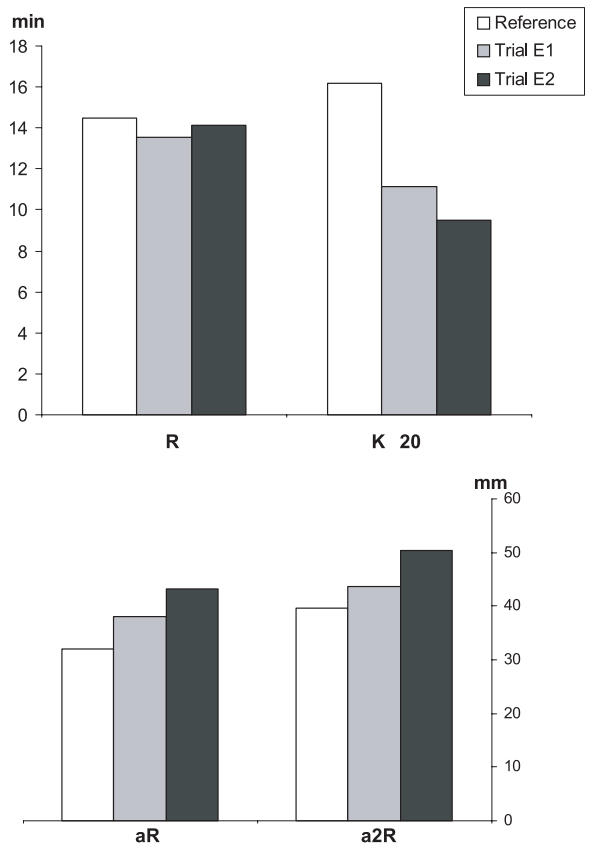

Figure 2. Rennet coagulation parameters of the three different milks. R: coagulation time; K20: firmness kinetics; aR: coagulum firmness after time equal to R; a2R:coagulum firmness after time equal to twice $R$. great change in the curd structure led to us not using $\mathrm{E}_{2}$ cheese milks to make Kashkaval cheeses on the pilot scale.

The average compositions of wheys collected $30 \mathrm{~min}$ after scalding (in hot brine $72{ }^{\circ} \mathrm{C}-14 \% \mathrm{NaCl}$ ) and pressing of the curd are given in Table III. Total solids and fat contents decreased in wheys expelled from casein-enriched cheese milks, but if the different nitrogen forms were lower in $E_{1}$ wheys than in reference cheese milks, that was not the case for $\mathrm{E}_{2}$ wheys. The determined increases (per kg: $+2.2 \mathrm{~g}$ in TNM; $+0.8 \mathrm{~g}$ in $\mathrm{NCN} ;+1.4 \mathrm{~g}$ in casein) confirmed the inability of $\mathrm{E}_{2}$ curds to be handled in an identical way to the other cheese milks.

The average compositions of bench reference and $E_{1}$ cheeses after 45 days of ripening are given in Table IV. Increase in casein content of the cheese milks did not alter the biochemical or physical parameters $\left(\mathrm{pH}\right.$ and $\left.\mathrm{a}_{\mathrm{w}}\right)$ of the cheeses, probably because of the casein/fat ratio standardisation of the milk to the value of $0.78 \pm 0.03$.

The proportions of total solids, fat and TNM recovered in the cheeses are shown in Table V. Casein enrichment from $22.90 \pm$ $0.01 \mathrm{~g} \cdot \mathrm{kg}^{-1}$ to $26.10 \pm 0.02 \mathrm{~g} \cdot \mathrm{kg}^{-1}$ increased the fat recovery by $2.5 \%$ and the casein

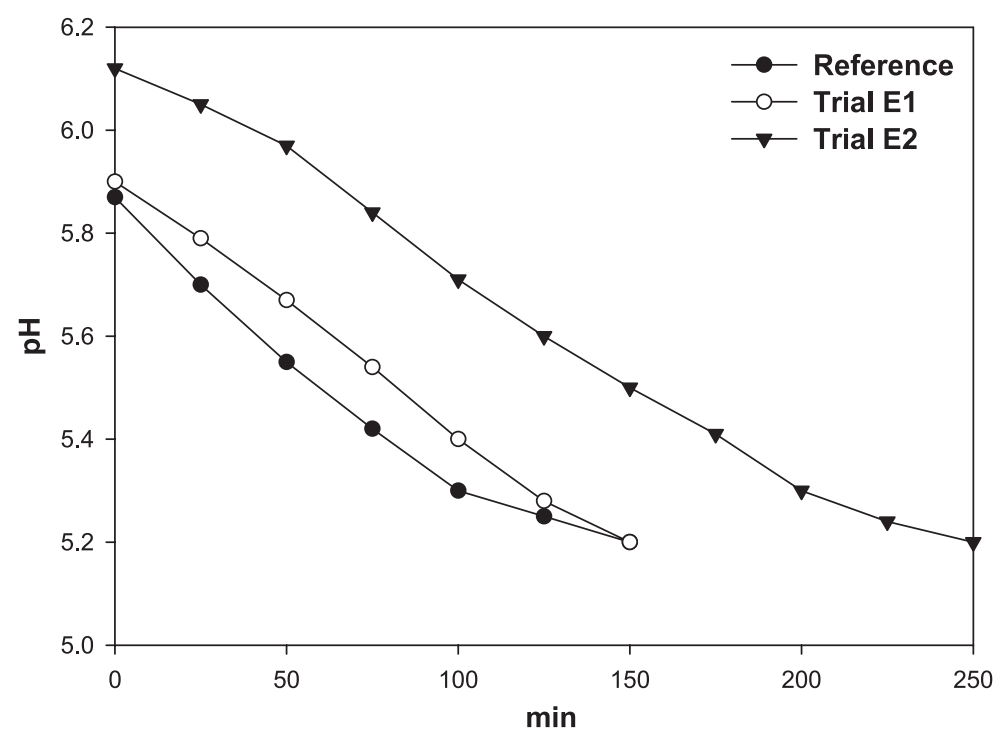

Figure 3. Lactic acidification of the three curd types. 
Table III. Average composition of whey expelled $30 \mathrm{~min}$ after curd scalding and pressing.

\begin{tabular}{lccc}
\hline $\begin{array}{l}\text { Contents } \\
\left(\mathrm{g}^{-1}{ }^{-1}\right)\end{array}$ & Reference & Products & Trial $_{2}$ \\
\cline { 2 - 4 } & $62.0 \pm 0.18$ & $60.10 \pm 0.15$ & $59.80 \pm 0.12$ \\
Total solids & $2.50 \pm 0.02$ & $2.20 \pm 0.01$ & $2.00 \pm 0.1$ \\
Fat & $10.3 \pm 0.05$ & $9.40 \pm 0.04$ & $12.50 \pm 0.06$ \\
TNM $(\mathrm{N} \times 6.38)$ & $7.50 \pm 0.05$ & $7.00 \pm 0.07$ & $8.30 \pm 0.07$ \\
NCN & $2.10 \pm 0.02$ & $2.10 \pm 0.02$ & $2.20 \pm 0.02$ \\
NPN & $2.80 \pm 0.05$ & $2.40 \pm 0.02$ & $4.20 \pm 0.07$ \\
Casein &
\end{tabular}

Table IV. Composition of ripened cheese (d45).

\begin{tabular}{lcc}
\hline Contents & \multicolumn{2}{c}{ Products } \\
\cline { 2 - 3 } & Reference & Trial $\mathrm{E}_{1}$ \\
\hline Total solids $\left(\mathrm{g} \cdot \mathrm{kg}^{-1}\right)$ & 622.10 & 622.90 \\
$\mathrm{TNM}\left(\mathrm{g} \cdot \mathrm{kg}^{-1}\right)$ & 287.60 & 289.90 \\
$\mathrm{NCN}\left(\mathrm{g} \cdot \mathrm{kg}^{-1}\right)$ & 25.80 & 27.10 \\
$\mathrm{NPN}\left(\mathrm{g} \cdot \mathrm{kg}^{-1}\right)$ & 12.20 & 13.30 \\
Casein $\left(\mathrm{g} \cdot \mathrm{kg}^{-1}\right)$ & 261.80 & 262.80 \\
Fat/TS $(\%)$ & 46.59 & 46.66 \\
Casein/TS $(\%)$ & 42.08 & 42.19 \\
Casein/TNM $(\%)$ & 96.53 & 96.40 \\
$\mathrm{NaCl}$ in moisture $(\%)$ & 2.46 & 2.10 \\
Ashes $(\%)$ & 47.80 & 50.40 \\
$\mathrm{P}(\%)$ & 0.53 & 0.55 \\
Ca $(\%)$ & 0.87 & 0.91 \\
$\mathrm{~K}(\%)$ & 0.61 & 0.67 \\
$\mathrm{Na}(\%)$ & 2.02 & 2.04 \\
$\mathrm{Mg}(\%)$ & 0.030 & 0.032 \\
$\mathrm{pH}$ & 5.33 & 5.45 \\
Water activity & 0.924 & 0.926 \\
\hline
\end{tabular}

Table V. Total solids, fat and TNM recovery percentages and cheese yields.

\begin{tabular}{lcc}
\hline Recovery & \multicolumn{2}{c}{ Products } \\
\cline { 2 - 3 } & Reference & Trial E $_{1}$ \\
\hline Total solids & 45.91 & 50.36 \\
Fat & 77.39 & 79.93 \\
TNM & 75.94 & 76.73 \\
Casein & 95.36 & 98.87 \\
Yield in kg per 100 kg of cheese milk & & \\
observed & 8.15 & 9.53 \\
corrected $\left(40 \% \mathrm{H}_{2} \mathrm{O}\right)$ & 8.45 & 9.88 \\
\hline
\end{tabular}


recovery by $3.5 \%$. The cheese yielding capacity either for non-corrected or for $40 \%$ moisture was increased by $16.9 \%$.

\section{CONCLUSION}

This study demonstrates that totally satisfactory Kashkaval cheese can be obtained from cow's milk whose casein content is standardised to $26.10 \pm 0.02 \mathrm{~g} \cdot \mathrm{kg}^{-1}$ by addition of native micellar casein obtained through a MF membrane of $0.1 \mu \mathrm{m}$. Improved recoveries of total solids $(+4.4 \%)$, fat $(+2.5 \%)$ and casein $(+3.5 \%)$ were determined, as well as a high increase in cheese yield $(+16.9 \%)$. A higher increase in the casein content to $29.20 \pm 0.02 \mathrm{~g} \cdot \mathrm{kg}^{-1}$ if it accelerated curd matrix formation $(\mathrm{K} 20=$ $9 \mathrm{~min}$ and $51 \mathrm{~s}$ vs. $16 \mathrm{~min}$ and $19 \mathrm{~s}$ in reference milk) certainly requires changes in the process parameters in order to have satisfactory acid production and cheddaring times, and cheese texture.

Acknowledgements: We are grateful to M.N. Madec and N. Leconte, who prepared starters and realised measurements of rennet coagulation parameters with the Formagraph equipment.

\section{REFERENCES}

[1] Ashaffenburg R., Drewry J., New procedure for the routine determination of the varions non casein proteins of milk, in: 15 th Int. Dairy Congr., vol. 3, 1959, pp. 1631-1637.

[2] Brulé G., Maubois J.L., Fauquant J., Étude de la teneur en éléments minéraux des produits obtenus lors de l'ultrafiltration du lait sur membrane, Lait 54 (1974) 600-615.

[3] Caric M., Milanovic S., Recent advances in Kashkaval cheese technology, in: Proc. 3rd California cheese symposium, University of California, Davis, USA, 1994, pp. 1-17.

[4] Caron A., Saint-Gelais D., Pouliot Y., Coagulation of milk enriched with ultrafiltered or diafiltered microfiltered milk retentate powder, Int. Dairy J. 7 (1997) 445-451.

[5] Daviau C., Pierre A., Famelart M.H., Goudédranche H., Jacob D., Garnier M., Maubois J.L., Whey drainage during soft cheese manufacture and properties of drained curds modified by casein concentration, whey protein to casein ratio and pasteurisation of milk, Lait 80 (2000) 573-587.
[6] FIL-IDF, Fromages et fromages fondus. Détermination de la teneur en phosphore total (Méthode phosphométrique), Standard 33C, 1987.

[7] Garnot P., Influence of milk concentration by UF on enzymatic coagulation, Bull. Int. Dairy Fed. 225 (1988) 11-15.

[8] Kindstedt P., Caric M., Milanovic S., Pasta filata cheeses, in: Fox P.F., McSweeney P.L.H., Cogan T.M., Guinee T.P. (Eds.), Cheese: chemistry, physics and microbiology, 3rd edn., vol. 2, Elsevier, New York, USA, 2004, pp. 251-277.

[9] Lawrence R.C., Gilles J., Creamer L.K., Crow V.L., Heap H.A., Honore C.G., Johnston K.A., Samal P.K., Cheddar cheese and related dry-salted cheese varieties, in: Fox P.F., McSweeney P.L.H., Cogan T.M., Guinee T.P. (Eds.), Cheese: chemistry, physics and microbiology, 3rd edn., vol. 2, Elsevier, New York, USA, 2004, pp. 71-102.

[10] Maubois J.L., Mocquot G., Préparation de fromage à partir de préfromage liquide obtenu par ultrafiltration sur membrane, Lait 51 (1971) 495-533.

[11] Maubois J.L., Fauquant J., Famelart M.H., Caussin F., Milk microfiltrate, a convenient starting material for fractionation of whey proteins and derivatives, in: Proc. 3rd Int. Whey Conf., Munich, Germany, 2001, pp. 59-72.

[12] Pierre A., Fauquant J., Le Graët Y., Piot M., Maubois J.L., Préparation de phosphocaséinate natif par microfiltration sur membrane, Lait 72 (1992) 461-474.

[13] Saboya L., Maubois J.L., Current developments of microfiltration technology in the dairy industry, Lait 80 (2000) 541-553.

[14] Saint-Gelais D., Piette M., Bélanger G., Production of Cheddar cheese using milk enriched with microfiltered milk retentate. A preliminary study, Milchwissenschaft 50 (1995) 614-618.

[15] Saint-Gelais D., Roy D., Audet P., Manufacture and composition of low fat Cheddar cheese from milk enriched with different protein concentrate powders, Food Res. Int. 31 (1998) 137-145.

[16] Schuck P., Piot M., Méjean S., Le Graët Y., Fauquant J., Brulé G., Maubois J.L., Déshydration par atomisation de phosphocaséinate natif obtenu par microfiltration sur membrane, Lait 74 (1994) 375-388.

[17] Vandeweghe J., Cheese yield, evaluation and measurement, in: Cheesemaking, 2nd edn., Tec \& Doc Lavoisier, Paris, France, 2000, pp. 738-747. 